\title{
Heterologous Hyaluronic Acid Production in Kluyveromyces lactis
}

\author{
Antonio M. V. Gomes, João H. C. M. Netto (), Lucas S. Carvalho and Nádia S. Parachin *( \\ Grupo de Engenharia de Biocatalisadores, Departamento de Biologia Celular, Instituto de Ciências Biológicas, \\ Universidade de Brasília (UnB), Campus Darcy Ribeiro, Bloco K. Brasilia, Federal District 70790-900, Brazil \\ * Correspondence: nadiasp@unb.br
}

Received: 15 July 2019; Accepted: 11 August 2019; Published: 28 August 2019

check for updates

\begin{abstract}
Hyaluronic Acid (HA) is a biopolymer composed by the monomers Glucuronic Acid (GlcUA) and N-Acetyl Glucosamine (GlcNAc). It has a broad range of applications in the field of medicine, being marketed between USD $1000-5000 / \mathrm{kg}$. Its primary sources include extraction of animal tissue and fermentation using pathogenic bacteria. However, in both cases, extensive purification protocols are required to prevent toxin contamination. In this study, aiming at creating a safe HA producing microorganism, the generally regarded as safe (GRAS) yeast Kluyveroymyces lactis is utilized. Initially, the hasB (UDP-Glucose dehydrogenase) gene from Xenopus laevis (xlhasB) is inserted. After that, four strains are constructed harboring different has $A$ (HA Synthase) genes, three of humans (hshas A1, hshasA2, and hshasA3) and one with the bacteria Pasteurella multocida (pmhasA). Transcript values analysis confirms the presence of has $A$ genes only in three strains. HA production is verified by scanning electron microscopy in the strain containing the pmHAS isoform. The pmHAS strain is grown in a $1.3 \mathrm{~L}$ bioreactor operating in a batch mode, the maximum HA levels are $1.89 \mathrm{~g} / \mathrm{L}$ with a molecular weight of $2.097 \mathrm{MDa}$. This is the first study that reports HA production in K. lactis and it has the highest HA titers reported among yeast.
\end{abstract}

Keywords: Hyaluronic Acid; Hyaluronic Acid Synthase; Kluyveromyces lactis; Pasteurella multocida; Xenopus laevis

\section{Introduction}

Hyaluronic acid (HA) is a glycosaminoglycan (GAG) composed by two molecules: the glucuronic acid (GlcUA) and $N$-acetyl glucosamine (GlcNAc) [1] (Figure 1). It is absent in insects and plants and occurs naturally in all vertebrates, also in algae and mollusks [2]. In the vast majority of fungi, HA is absent, but in some cases, as in the yeast Cryptococcus neoformans [3], this polymer is present. In vertebrates, HA is known for participating in cell migration, communication, adhesion, growth, and differentiation, as well as tissue repair and angiogenesis [4]. Is expected that the HA global market will reach approximately U\$D 15.25 Billion by 2026 with a Compound Annual Growth Rate (CAGR) of $7.8 \%$ [5]. Its increased demand over the years is associated with its application in various fields related to aesthetics, pharmaceuticals, and medicine. Currently, several medical techniques use HA such as in orthopedic [6] and ophthalmologic procedures and for wrinkle reduction in anti-aging treatment [7]. 


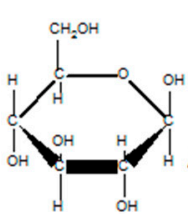

GLUCOSE

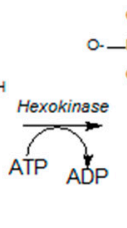

GLUCOSE-6-PHOSPHATE

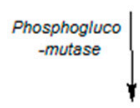<smiles>O=C[C@H]1O[C@H](OP(=O)([O-])[O-])[C@@H](O)[C@H](O)[C@H]1O</smiles>

GLUCOSE-1-PHOSPHATE
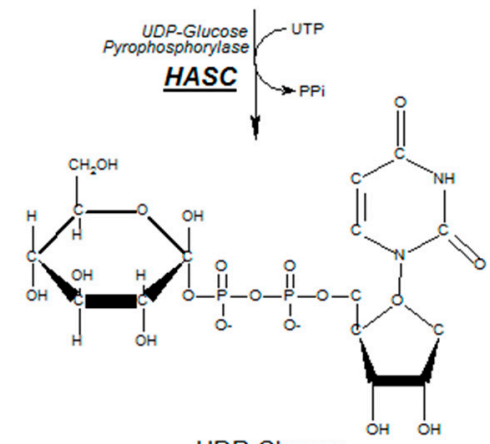

UDP-Glucose

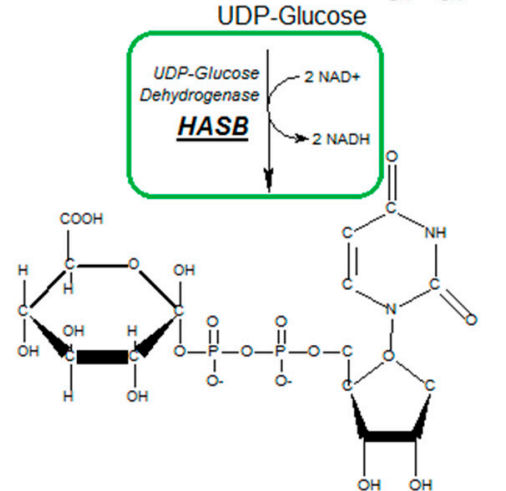

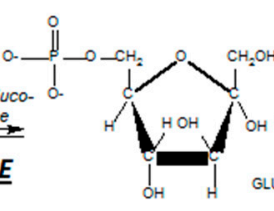

FRUCTOSE-6 PHOSPHATE
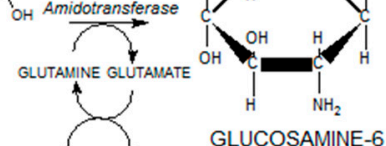

GLUCOSAMINE-6
-PHOSPHATE
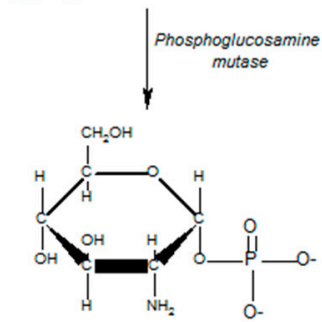

GLUCOSAMINE-1-PHOSPHATE
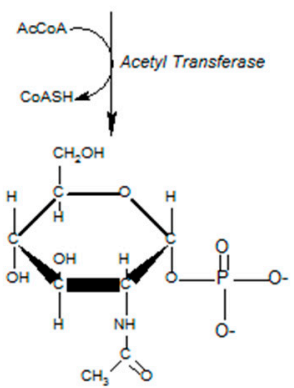

N-ACETYL-GLUCOSAMINE

-1-PHOSPHATE
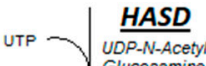

Pyrophosphe

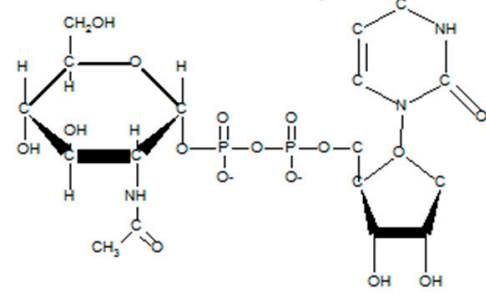

UDP-N-ACETYL-GLUCOSAMINE

UDP-GLUCURONIC ACID

Cytoplasm

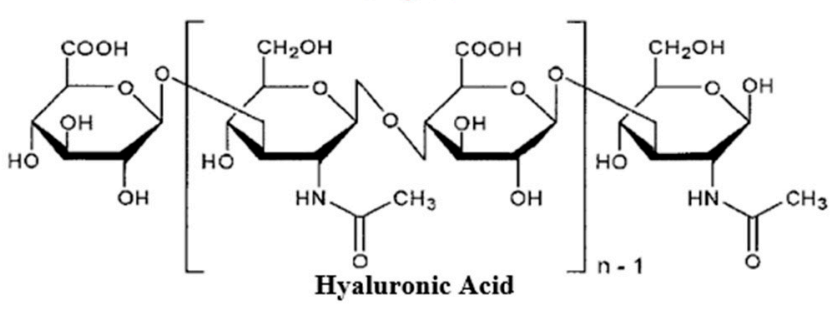

Space

Figure 1. The metabolic pathway for Hyaluronic Acid production. In green, the enzymes that are not present in the metabolism of $K$. lactis but are necessary for the synthesis of Hyaluronic Acid. 
The metabolic route to produce HA is highly conserved among different organisms (Figure 1). Both UDP-glucuronic acid (UDP-GlcUA) and UDP-N-acetyl glucosamine (UDP-GlcNAc) are synthesized from glycolytic precursors, the first from glucose-6-phosphate and the latter from fructose-6-phosphate (Figure 1). The last step during HA synthesis is catalyzed by the Hyaluronan Synthases or HA Synthases (HAS). HAS enzymes are coupled to cell membranes of organisms and are responsible for alternating the ligation of UDP-GlcUA and UDP-GlcNAc and exporting it to the extracellular environment (Figure 1). HAS enzymes are divided into two distinct classes: class I comprise all vertebrates, bacteria and a few other microorganisms and class II present only in the bacteria Pasteurella multocida [8-13]. The latter has differences in the transmembrane domains, structural organization, and mode of activity [11]. In class II enzyme, the elongation of HA is by the non-reducing end, different from all other HAS enzymes belonging to class I [13]. Among others, the class I of HAS comprises the three isoforms present in humans (Homo sapiens) that are encoded, respectively, by the genes hshas $A 1$, hshas $A 2$, and hshas $A 3$ [12]. These three isoforms have different kinetic parameters, which result in an HA with different chain sizes [12].

Primarily, HA was obtained from rooster combs, bovine vitreous humor, and umbilical cord [14]. In animal tissues, HA is coupled with proteoglycans that need to be removed from the biopolymer to allow its commercialization. These processes are laborious and costly and, therefore, novel processes for HA production based on microbial fermentation were developed. Naturally, HA production has been reported in the Streptococci genus [15]. Only this group of bacteria and Pasteurella multocida can naturally synthesize HA. Usually, fermentations using Streptococcus cells results in titers ranging from 0.3 up to $4.6 \mathrm{~g} / \mathrm{L}$ [16] with polymer sizes ranging from 1 to 4 Mega Daltons (MDa). However, because of its pathogenicity factors, the HA produced by Streptococci cells also requires a rigorous and costly purification process.

Thus, the HA biosynthetic pathway has been transferred to other non-pathogenic microorganisms such as Lactococcus lactis [17], Escherichia coli [18], Bacillus subtilis [19-21], Agrobacterium sp. [22], Corynebacterium glutamicum [23], Streptomyces albulus [24], and plant cell cultures [25]. In yeasts, Pichia pastoris (Komagataella spp.) has been previously utilized as a platform for HA production [26]. Here, for the first time, the Kluyveromyces lactis metabolism was modified for enabling HA production. $K$. lactis has a status generally regarded as safe (GRAS) and is commonly utilized to produce dairy products. Moreover, unlike other yeasts, K. lactis is advantageous for HA production because: (I) its respiratory metabolism with absence of ethanol production; (II) its central metabolism with carbon flow diverted to Pentose Phosphate Pathway (PPP) [27] that produces precursors necessary for HA synthesis, (III) its availability of sequenced genome [28] and establishment in genetic manipulation protocols, (IV) it is a consolidated platform for heterologous protein production [29], and finally (V) during process optimization, it is possible to achieve high cell density in $\mathrm{K}$. lactis using low-cost carbon sources such as lactose and whey, which also serve as inductors of strong promoters in this yeast.

According to the genome annotation of the K. lactis NRRL Y-1140 strain, the biosynthetic pathway of HA is incomplete. The yeast possesses all precursors for the synthesis of UDP-GlcNAc (Figure 1) while the metabolic pathway for the UDP-GlcUA production is incomplete (Figure 1). Therefore, to overcome this barrier, two genes were inserted into the K. lactis genome to complete the HA synthesis: (i) the hasB (UDP-Glucose Dehydrogenase) gene from Xenopus laevis (xlhasB) and (ii) the has A (HA Synthase). In all constructed strains, the same xlhas $B$ gene was utilized in combination with different versions of the has $A$ encoding gene.

Up to now, heterologous microorganisms that synthesize HA generally uses the class I of HAS enzymes [2]. Therefore, here for the first time HAS of class I and II were used to compare the HA production. Four distinct recombinant strains of $K$. lactis were constructed (Figure 2) containing each the three humans (Homo sapiens) Class I hasA genes (hshasA1, hshas A2, and hshasA3) and the Class II has A gene from Pasteurella multocida (pmhasA). Both the hasA genes from Homo sapiens [12,30-33] and $P$ multocida [34] were previously characterized and for this reason they were chosen for insertion 
in K. lactis. In addition, Xenopus laevis is a standard organism used in the study of HA synthesis [35], and the genes (has $A$ and has $B$ ) of this organism have also been previously characterized.

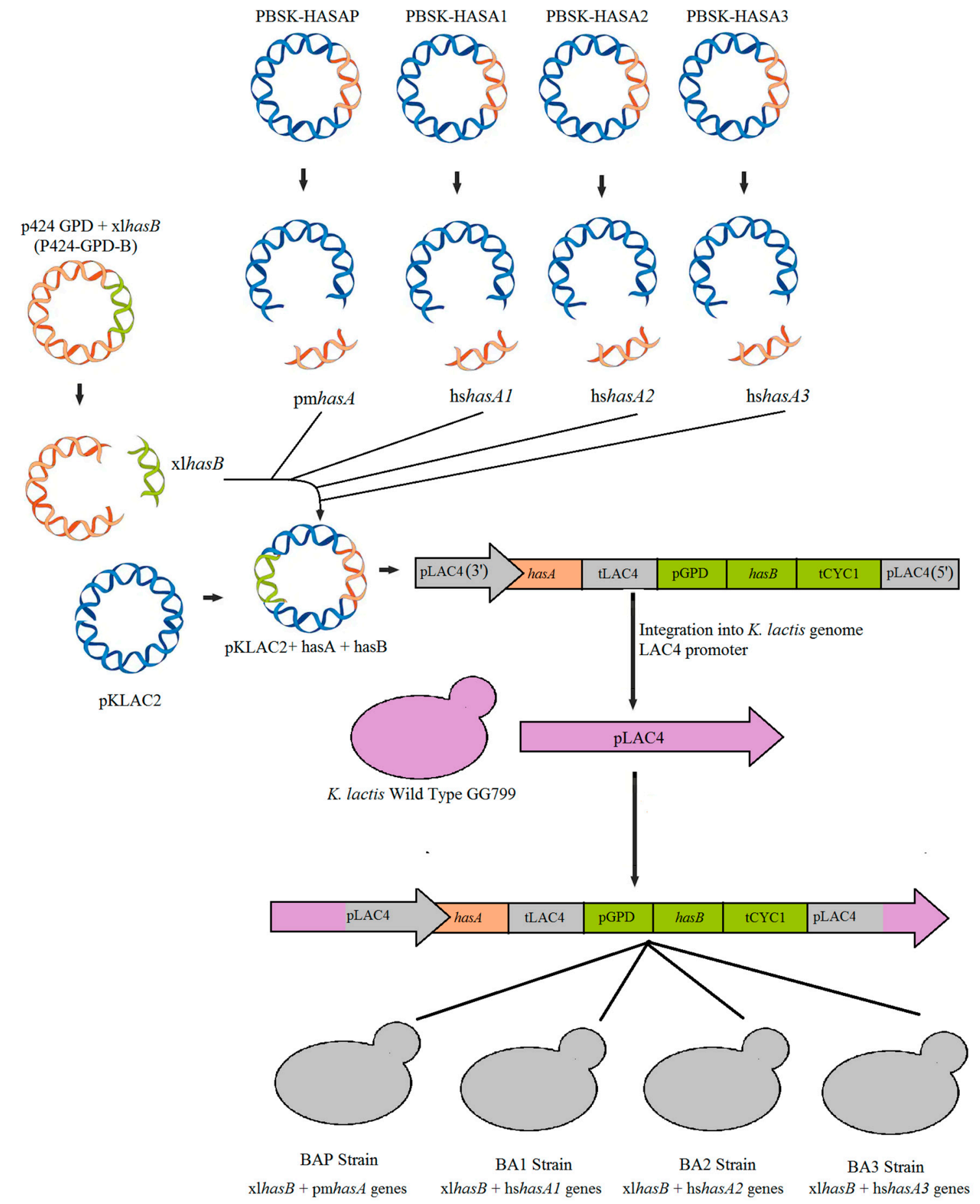

Figure 2. Overall construction strategy for the four strains generated in this study. The has $B$ gene from Xenopus laevis (xlhasB) and the different versions of has A genes from Homo sapiens (hshasA1, hshasA2, and hshas A3) and Pasteurella multocida (pmhasA) were inserted into the integrative plasmid pKlac2 for recombination in the LAC4 promoter of the K. lactis genome. 


\section{Materials and Methods}

\subsection{Microorganisms and Plasmids}

All strains and plasmids used in this study are described in Table 1. All plasmids maps and sequences used during this study are described in the Figures S1-S11 and Sequences S1-S11. Plasmid replication was done in E. coli strain XL-10 Gold using the heat shock protocol as previously described [36]. Transformants cells were selected in LB plates (yeast extract $5 \mathrm{~g} / \mathrm{L}$, tryptone $10 \mathrm{~g} / \mathrm{L}$, $\mathrm{NaCl} 10 \mathrm{~g} / \mathrm{L}$ and agar $20 \mathrm{~g} / \mathrm{L}$ in pH 7.0) containing ampicillin in a final concentration of $100 \mu \mathrm{g} / \mathrm{mL}$.

Table 1. Plasmids and strains used in this study.

\begin{tabular}{|c|c|c|}
\hline Plasmids & Description & Reference \\
\hline PBSK-HASB & The synthetic plasmid containing xlhasB optimized & This study \\
\hline PBSK-HASA1 & The synthetic plasmid containing hshas $A 1$ optimized & This study \\
\hline PBSK-HASA2 & The synthetic plasmid containing hshas $A 2$ optimized & This study \\
\hline PBSK-HASA3 & The synthetic plasmid containing hshas $A 3$ optimized & This study \\
\hline PBSK-HASAP & The synthetic plasmid containing pmhas $A$ optimized & This study \\
\hline P424-GPD & Commercial Plasmid containing GPD Promoter & $\mathrm{ATCC}^{\circledR}$ \\
\hline P424-GPD-B & P424-GPD + xlhasB gene & This study \\
\hline PKLAC2 & Commercial Plasmid for K. lactis protein expression & New England Biolabs \\
\hline PKLAC2-B & $\mathrm{pKlac}+\mathrm{xlhasB}$ gene & This study \\
\hline PKLAC2-BP & $\mathrm{pKlac}+\mathrm{xlhas} B$ gene $+\mathrm{pm} h a s A$ gene & This study \\
\hline PKLAC2-B1 & pKlac + xlhasB gene + hshas $A 1$ gene & This study \\
\hline PKLAC2-B2 & $\mathrm{pKlac}+\mathrm{xlhas} B$ gene + hshas $A 2$ gene & This study \\
\hline PKLAC2-B3 & pKlac + xlhasB gene + hshas $A 3$ gene & This study \\
\hline Strains & Description & Reference \\
\hline E. coli X110-Gold & The strain used for plasmids replication & Stratagene \\
\hline K. lactis GG799 & Wild-type yeast & New England Biolabs \\
\hline K. lactis BAP & Yeast containing $\mathrm{xl}$ has $B$ and pmhas $A$ genes & This study \\
\hline K. lactis BA1 & Yeast containing $\mathrm{xl}$ has $B$ and hshas $A 1$ genes & This study \\
\hline K. lactis BA2 & Yeast containing xlhasB and hshas $A 2$ genes & This study \\
\hline K. lactis BA3 & Yeast containing $\mathrm{xl} h a s B$ and hshas $A 3$ genes & This study \\
\hline
\end{tabular}

\subsection{Plasmids Construction}

The overall process for plasmid construction is summarized in Figure 2. All heterologous genes used in this study were previously optimized for expression in K. lactis and delivered in the pBSK vector (Table 1).

Initially, the xlhasB gene was removed from the pBSK-HASB and cloned into the plasmid p424GPD (Figure 2). After that, the construction of the $K$. lactis expression vectors was initiated by amplifying the has $B$ expression cassette containing the GPD promoter and CYC1 terminator and inserted into pKlac2 (New England Biolabs Inc, Ipswich, MA, USA). The resulting plasmid was named pKlac2-B (Table 1). Next, for the insertion of hasA genes, all pBSK-HASAP, pBSK-HASA1, pBSK-HASA2, and pBSK-HASA3 plasmids were treated with HindIII and StuI. The resulting fragments were ligated into the pKlac2-B previously treated with the same restriction enzymes. The four resulting plasmids, pKlac2-BP, pKlac2-B1, pKlac2-B2, and pKlac2-B3 (Table 1 and Figure 2), containing both xlhasB and has A genes were sequenced before yeast transformation. All primers utilized in this study are summarized in Table S1.

\subsection{Nucleotide Sequence Accession Numbers}

The codon-optimized sequences of a hasB gene from Xenopus laevis, has A gene from Pasteurella multocida and the three has $A$ genes from Homo sapiens were deposited in GenBank under accession numbers MH728986, MH728990, MH728987, MH728988, and MH728989, respectively. 


\subsection{Transformation of Kluyveromyces lactis Cells}

K. lactis strain GG799 cells were transformed using linearized plasmids with SacII. After linearization with SacII, the plasmids constructed from pKlac2 released a cassette for integration into the LAC4 promoter of K. lactis (Figure 2). Yeast transformation was done by using the "K. lactis Protein Expression Kit" from NEB (New England Biolabs) following the manufacturer's recommendations. Transformants were selected in YCB acetamide agar (1.17\% YCB medium, acetamide $5 \mathrm{mM}$, sodium phosphate buffer $30 \mathrm{mM}$, and agar $2 \%$ ). The plates were incubated at $30{ }^{\circ} \mathrm{C}$ for $3-4$ days.

Gene integration was confirmed by colony PCR using the primers listed in Table S1. Genomic DNA of strains was extracted using the GeneJET Genomic DNA Purification Kit (Thermo Fisher Scientific, MA, EUA) according to the manufacturer's protocol.

\subsection{Growth of K. lactis Strains BAP, BA1, BA2, and BA3 in Shake Flask}

All strains of $K$. lactis constructed in this study, in addition to the wild-type, GG799 strain, were grown in $250 \mathrm{~mL}$ shake flasks during $24 \mathrm{~h}$ containing $100 \mathrm{~mL}$ of a modified YPD medium as previously described [37]. Briefly the medium was composed by $7.5 \mathrm{~g} / \mathrm{L}$ yeast extract, $10 \mathrm{~g} / \mathrm{L}$ peptone, $40 \mathrm{~g} / \mathrm{L}$ glucose, $2.5 \mathrm{~g} / \mathrm{L} \mathrm{K}_{2} \mathrm{HPO}_{4}, 0.9 \mathrm{~g} / \mathrm{L} \mathrm{MgSO}{ }_{4} 7 \mathrm{H}_{2} \mathrm{O}, 5 \mathrm{~g} / \mathrm{L} \mathrm{NaCl}, 0.4 \mathrm{~g} / \mathrm{L}$ glutamine and $0.6 \mathrm{~g} / \mathrm{L}$ glutamate. The cells were grown at $30{ }^{\circ} \mathrm{C}$ and $200 \mathrm{rpm}$. Monitoring of cell growth in shake flasks was carried every $2 \mathrm{~h}$ with the reading of the cell density in a SpectraMax M2 microplate reader (Molecular Devices $\left.{ }^{\circledR}\right)$ in $\mathrm{OD}_{600}$.

\subsection{Detection of the has $B$, has $A 1$, has $A 2$, has $A 3$ and has $A P$ Gene Transcripts}

As described before, all strains constructed in this study were grown in shake flask until early exponential phase $\left(\mathrm{OD}_{600}=\sim 1.0\right)$. At this time, $2 \mathrm{~mL}$ of cells were collected and subjected to total RNA extraction using TRIzol reagent (Invitrogen, Carlsbad, EUA) according to the manufacturer's recommendations. Only samples containing $\mathrm{OD}_{260 / 280}>1.8$ were utilized for transcript values analysis.

For checking RNA integrity, all samples were analyzed on a bleach agarose gel as previously described [38] (Figures S12 and S13). After selecting the RNAs with a reasonable degree of purity and integrity, about 1.0 ug of total RNA was used as a template for reverse transcription using SuperScript ${ }^{\circledR}$ III Reverse Transcriptase kit (Thermo Fisher Scientific) according to the manufacturer's recommendations. The resulting cDNA from the wild-type strain GG799 and BAP, BA1, BA2 and BA3 strains was used as template in real-time PCR reaction using the following conditions: initial denaturation for $10 \mathrm{~min}$ at $95^{\circ} \mathrm{C} ; 40$ cycles of $95^{\circ} \mathrm{C}$ for 15 s-optimum temperature of each primer for $30 \mathrm{~s}-72{ }^{\circ} \mathrm{C}$ for $30 \mathrm{~s}$, and $72{ }^{\circ} \mathrm{C}$ for $60 \mathrm{~s}$. Each reaction of $20 \mu \mathrm{L}$ was constructed using SYBR ${ }^{\circledR}$ Green PCR Master Mix (Thermo Fisher Scientific) according to the manufacturer's recommendations. The melting curve of all transcripts obtained in this study was used to visualize the correct specificity of each pair of primers (Figures S14-S18).

\subsection{Gene Copy Number Quantification}

Gene copy number of pmhas $A$ and xlhasB was confirmed only in BAP strain by qPCR as previously described [39]. The Actin gene was used as endogenous control because it is present in only one copy according to the online genome database of $K$. lactis.

After genomic DNA extraction and purification, $100 \mathrm{ng}$ of it was distributed in qPCR reactions containing dilutions of $100,10,1,0.1$ and $0.01 \mathrm{ng} /$ reaction in a $20-\mu \mathrm{L}$ mixture. The values of $C_{T}$ obtained were used to construct an efficiency curve of each primer utilized. Only the reactions containing values of efficiency amplification between $90 \%$ and $110 \%$ were used for calculation of fold-change.

Quantitative PCR (qPCR) was performed using SYBR ${ }^{\circledR}$ Green PCR Master Mix (Thermo Fisher Scientific) according to the manufacturer's recommendations with a StepOne ${ }^{\mathrm{TM}}$ Real-Time PCR System (Applied Biosystems, CA, EUA). 


\subsection{Microscopic Analysis of Recombinant K. lactis Strains}

Cell images were obtained on a field emission scanning electron microscope (Jeol JSM-7000F) with the assistance of a metalized (Emitec K550) and critical drying point (Emitec K850). $1 \mathrm{~mL}$ of cells were collected after $24 \mathrm{~h}$ of growth in a shake flask, as described in Section 2.5. The cells were prepared for analysis, as previously described [40].

\subsection{Batch Fermentations of K. lactis Strains}

Batch fermentations of the Wild-type (GG799) and BAP strains were performed in New Brunswick BioFlo ${ }^{\circledR} 115$ bioreactors (Eppendorf AG, Hamburg, Germany) with a capacity of 1.3 L. Pre-inoculums of both strains were grown in $50 \mathrm{~mL}$ of Yeast Nitrogen Base (YNB) containing ammonium sulfate and amino acids (Sigma-Aldrich -St. Louis, MO, USA) in a flask with a capacity of $0.5 \mathrm{~L}$. The medium was prepared according to the manufacturer's recommendations using glucose $(40 \mathrm{~g} / \mathrm{L})$ as a carbon source. The strains grew for approximately $24 \mathrm{~h}$ at $30{ }^{\circ} \mathrm{C}$ and $200 \mathrm{rpm}$. This pre-culture was then used to inoculate $1 \mathrm{~L}$ of the same YNB medium in the fermenter with an initial $\mathrm{OD}_{600}=\sim 0.1$. The fermentation was conducted at $30^{\circ} \mathrm{C}$, and $200 \mathrm{rpm}$ in $1 \mathrm{~L}$. During all fermentations, the $\mathrm{pH}$ of the medium was maintained in 6.0 with the automatic injection of $\mathrm{NaOH} 2 \mathrm{M}$ from a feed base bottle, and the Dissolved Oxygen (DO) in 30\% kept in cascade using stirring and air flow at $2 \mathrm{vvm}$. All batch fermentations were performed in biological triplicate.

\subsection{Detection and Quantification of the Substrate and Cellular Products}

Glucose consumption and production of acetate, ethanol, lactate, and glycerol were quantified using High-Performance Liquid Chromatography (HPLC) (Shimadzu, Kyoto, Japan) equipped with refractive index and UV (210-nm) detectors. The chromatography was performed using a Shim-pack SCR-101H (Shimadzu) $\left(300 \mathrm{~mm} \times 7.9 \mathrm{~mm}\right.$ id) column equilibrated at $60^{\circ} \mathrm{C}$ with $5 \mathrm{mM} \mathrm{H}_{2} \mathrm{SO}_{4}$ as the mobile phase at a flow rate of $0.6 \mathrm{~mL} / \mathrm{min}$. The run was $59 \mathrm{~min}$ long. Cell growth was monitored by withdrawing $1 \mathrm{~mL}$ aliquots of medium fermentation every $2 \mathrm{~h}$ for reading at $600 \mathrm{~nm}$ using a SpectraMax M2 microplate reader (Molecular Devices ${ }^{\circledR}$ ).

\subsection{HA Quantification}

For HA quantification, the culture broth fermentation of all strains and a wild-type strain control was diluted with 1 volume of $0.1 \%$ SDS for uncoupling the HA capsule surrounding the cell wall. After $10 \mathrm{~min}$ at room temperature, the cells were centrifuged $6000 \times \mathrm{g} 4{ }^{\circ} \mathrm{C}$. After the supernatant was filtered with $0.20 \mu \mathrm{m}$ filter, then the HA was purified by washing the medium twice with 3-4 volumes of $100 \%$ ethanol. The HA pellet formed was resuspended in $50 \mathrm{~mL}$ of deionized water, and the Carbazol method was used for HA quantification as previously described [41]. A standard curve of HA concentrations ranging from 0.1 to $0.8 \mathrm{~g} / \mathrm{L}$ was made using HA 99\% Sigma-Aldrich (St. Louis, MO, USA). The samples were diluted $50 \times$ and $100 \times$ in deionized water before reading.

\subsection{HA Molecular Weight Determination}

The molar mass of HA was analyzed by performing Aqueous Gel Permeation Chromatography (GPC). The samples of HA were analyzed with a concentration of $10 \mathrm{mg} / \mathrm{mL}$. As a solvent, a $0.1 \mathrm{M}$ $\mathrm{NaNO}_{3}$ solution with the flow rate of $0.5 \mathrm{~mL} / \mathrm{min}$ was used in a Column System: 2SB-807 HQ, 2SB-806M HQ. The Injection Volume was $100 \mu \mathrm{L}$ with Refractive Index Detectors and Poly (Ethylene Oxide) standards (PEO). The "hyaluronic acid sodium salt from Streptococcus equi" utilized as a standard in GPC analysis was obtained from Sigma Aldrich (St. Louis, MO, USA) and contained 1.5 to $1.8 \mathrm{MDa}$ according to the manufacturer information. 


\section{Results}

\subsection{Growth Rate Determination and $H A$ Detection for BAP, BA1, BA2, and BA3 in Shake Flask}

All strains constructed in this study were named concerning the versions of has $A$ genes as listed in Table 1. The strains containing the genes pmhas $A$, hshas $A 1$, hshas $A 2$ and hshas $A 3$ were respectively named BAP, BA1, BA2, and BA3. All strains were grown on shake flask, and the growth rate on glucose was calculated. The BAP strain had a more extended lag phase in comparison to all constructed strains and the wild type (Figure S19). All strains, including the wild type, showed statistically the same growth rate (Table 2). Finally, by the end of the exponential growth phase, the final biomass of the BAP strain was about half of that obtained by the other four strains (Figure S19).

Table 2. Final $\mathrm{OD}_{600}$ and Growth Rate $\mu_{\mathrm{MAX}}\left(\mathrm{h}^{-1}\right)$ of all strains constructed in this study. The strains were grown in Shake Flasks. Values were obtained from biological triplicate.

\begin{tabular}{cccccc}
\hline Strain & GG799 & BAP & BA1 & BA2 & BA3 \\
\hline Final OD 600 & $42 \pm 3.5$ & $16.3 \pm 5.2$ & $36.9 \pm 5.0$ & $37.6 \pm 1.2$ & $38.7 \pm 3.5$ \\
$\mu_{\text {MAX }}\left(\mathbf{h}^{-1}\right)$ & $0.33 \pm 0.03$ & $0.28 \pm 0.03$ & $0.34 \pm 0.04$ & $0.35 \pm 0.02$ & $0.30 \pm 0.03$ \\
\hline
\end{tabular}

\subsection{Transcript Values of HAS Genes}

The analysis of transcripts values of all has $A$ and hasB genes were analyzed in all constructed strains. The actin transcript values were normalized to $100 \%$ to calculate the transcript values of the other genes. As it can be seen in Figure S20, the gene xlhasB was detected in all recombinant strains but at least with half of the transcript level when compared to actin. The has $A$ gene was detected only in strains BAP, BA1 and BA3 with about the same transcription levels but with about $60 \%$ of the transcript level for the actin gene. The number of copies of pmhas $A$ and $x 1 h a s B$ genes was quantified only in the HA producing strain (BAP). Each gene presented three copies (Figure S21).

\subsection{Microscopic Analysis of GG799, BAP, BA1, BA2, and BA3 Strains}

All constructed strains were analyzed by Electron Microscopy to investigate the presence of an HA capsule. As shown in Figure 3, the strains GG799 (Figure 3a), BA1 (Figure 3b), BA2 (Figure 3c), and BA3 (Figure 3d) did not produce any capsule. Nevertheless, the BAP strain was the only one that had a capsule around its cells corroborating HA production (Figure 3e,f). Indeed, in BAP, HA production could be detected already at 6-h of fermentation (Figure 3e).

\subsection{Batch Fermentation and Co-Product Formation}

The BAP and the wild-type GG799 strains were grown in a 1.3 L bioreactor to determine what was the possible changes in the co-product distribution resulted by the genetic modifications introduced for HA synthesis. As it can be seen in Table 3, the $\mu_{\text {Max }}$ values of BAP and GG799 are nearly the same. Nevertheless, the biomass yield was $19.5 \%$ lower in the BAP strain compared to the wild-type strain, corroborating a shift of carbon flux from cell growth to HA synthesis (Table 3). All these results were also observed in flasks' growth (Table 2).

Concerning the other metabolic products, glycerol formation was reduced almost seven times while ethanol increased nearly eight times in the BAP strain. Lactate was detected only in the wild-type strain at negligible values, whereas acetate was only produced in BAP strain also at negligible levels (Table 3). The HA concentration, according with Carbazole method quantification, resulted in $1.89 \mathrm{~g} / \mathrm{L}$. 


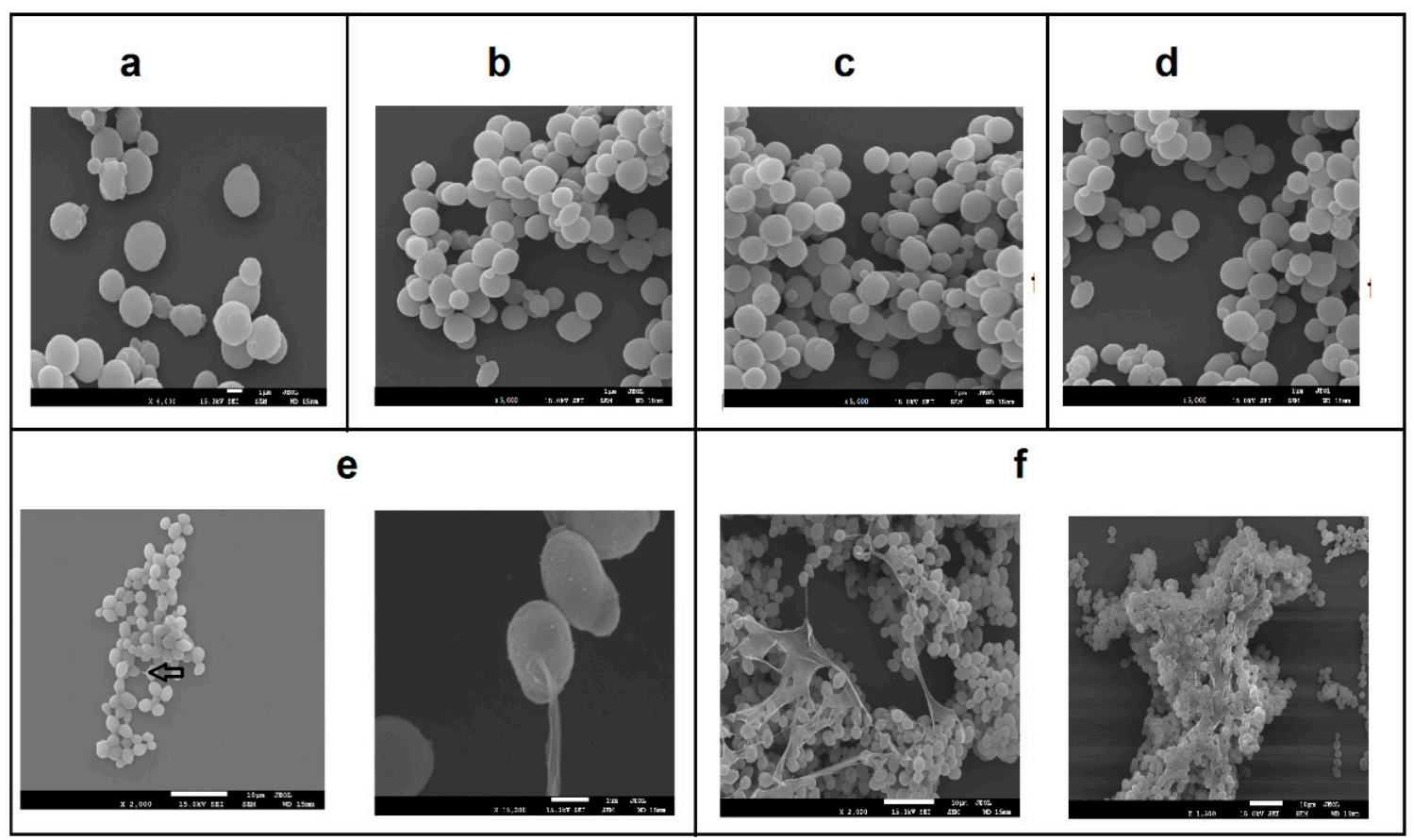

Figure 3. Scanning electron microscopy (SEM) analysis of the wild-type K. lactis GG799 strain and all strains constructed in this study. (a) GG799 strain (6000-fold increase) after $24 \mathrm{~h}$ of flask cultivation; (b) BA1 strain (5000-fold increase) after $24 \mathrm{~h}$ of flask cultivation; (c) BA2 strain (5000-fold increase) after $24 \mathrm{~h}$ of flask cultivation; (d) BA3 strain (5000-fold increase) after $24 \mathrm{~h}$ of flask cultivation; (e) BAP strain (5000-fold and 15000-fold increase) after $6 \mathrm{~h}$ of flask cultivation and (f) BAP strain after $24 \mathrm{~h}$ of flask cultivation in 5000-fold increase.

Table 3. Final $\mathrm{OD}_{600}$, Growth Rate $\mu_{\mathrm{MAX}}\left(\mathrm{h}^{-1}\right)$, Hyaluronic Acid production (g/L), Hyaluronic Acid Molecular Weight (MDa) and Yields of biomass (x), glycerol (gly), ethanol (et), lactate (lac) and acetate (ace) for all strains constructed. The strains were grown in bioreactor. Values were obtained from biological triplicate.

\begin{tabular}{cccccccccc}
\hline Strain & $\begin{array}{c}\text { Final } \\
\mathbf{O D}_{\mathbf{6 0 0}}\end{array}$ & $\boldsymbol{\mu}_{\mathbf{M A X}}\left(\mathbf{h}^{-\mathbf{1}}\right)$ & $\mathbf{H A}(\mathrm{g} / \mathbf{L})$ & $\begin{array}{c}\text { HA MW } \\
\mathbf{( M D a}\end{array}$ & $\mathbf{Y}_{\mathbf{x} / \mathbf{s}}$ & $\mathbf{Y}_{\text {gly/s }}$ & $\mathbf{Y}_{\text {Et/s }}$ & $\mathbf{Y}_{\text {lac/s }}$ & $\mathbf{Y}_{\text {ace/s }}$ \\
\hline GG799 & $77.6 \pm 1.4$ & $0.30 \pm 0.06$ & 0 & - & $0.42 \pm 0.03$ & $0.30 \pm 0.01$ & $0.04 \pm 0.02$ & $0.02 \pm 0.02$ \\
BAP & $40.2 \pm 5.9$ & $0.31 \pm 0.03$ & $1.89 \pm 0.2$ & $2.09 \pm 0.01$ & $0.34 \pm 0.02$ & $0.04 \pm 0.02$ & $0.32 \pm 0.04$ & 0 & $0.06 \pm 0.01$ \\
\hline
\end{tabular}

\subsection{HA Molecular Weight Determination}

GPC analyzes resulted in 3 elution peaks at the retention volumes of $27.88 \mathrm{~mL}, 37.89 \mathrm{~mL}$ and $44.87 \mathrm{~mL}$, (Figure 4$)$. The first $(27.88 \mathrm{~mL})$ and the later $(44.87 \mathrm{~mL})$ peaks represents compounds with molecular weight of 2.097 MDa and $192 \mathrm{Da}$, respectively. Considering that each disaccharide of HA contains 400 Da [14], the latter elutes (37.89 and 44.87) correspond to impurities contained in the samples. The GPC analysis of the standard HA (containing 1.5 MDa) obtained commercially and utilized for comparation is represented in Figure S22. The 2 peaks eluted in $32.75 \mathrm{~mL}$ and $46.13 \mathrm{~mL}$ in GPC analysis of HA standard represent populations with molecular weight of approximately 1.3 MDa and $126 \mathrm{Da}$, respectively (Figure S22). 


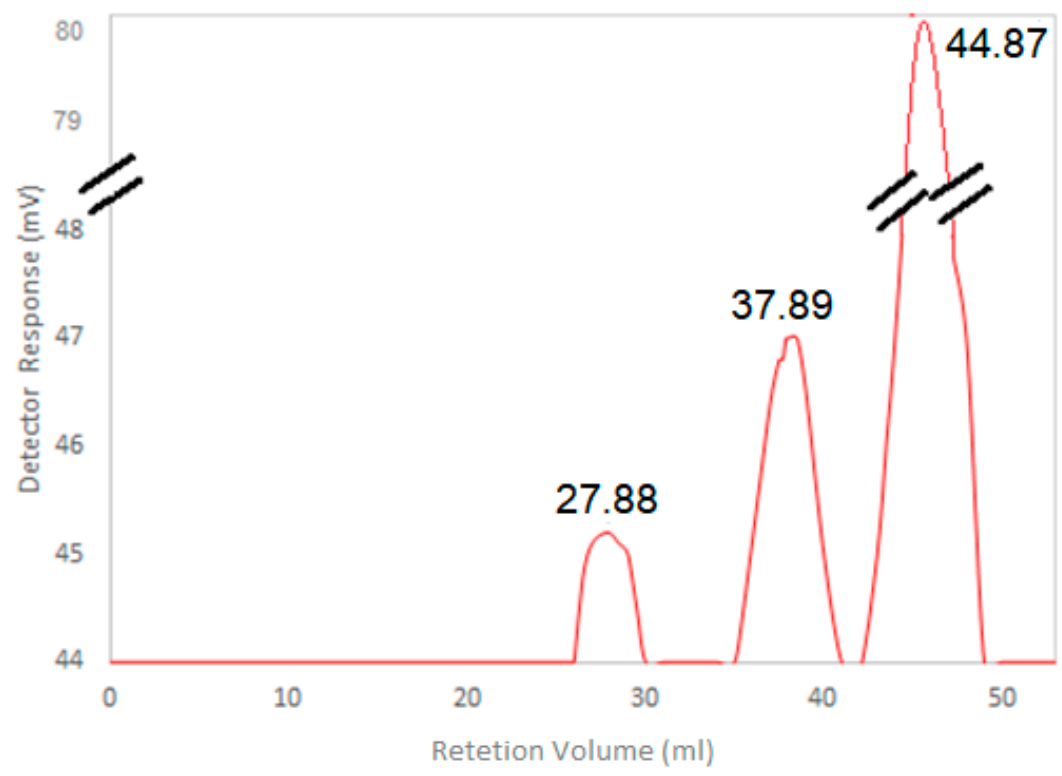

Figure 4. Gel Permeation Chromatography (GPC) analysis of the Hyaluronic Acid (HA) purified from BAP strain after growth in bioreactor.

\section{Discussion}

Except for Cryptococcus neoformans [42], yeasts are not able to produce Hyaluronic Acid. Up to now only the yeasts S. cerevisiae [43] and P. pastoris [26] (Komagataella phaffii) were previously genetically modified for HA production. In P. pastoris, for example, 5 genes (has $A$, has B, has C, hasD, and hasE) were inserted. Similarly, to $P$ pastoris, several other studies of HA production in genetic engineered modified microorganisms overexpress the has $C$, has $D$ and has $E$ genes in addition to has $A$ and has $B$. All these genes are generally chosen because in some $\mathrm{AH}$ producing bacteria, such as Streptococcus zooepidemicus subsp. equi, there is a dedicated operon for the synthesis of HA containing the genes has $A$, has $B$, has $C$, $h a s D$, and hasE [44]. Here HA production could be confirmed only by the addition of has $A$ and hasB.

Up to now, the microorganisms having the same genetic modifications introduced in this study (only the addition of has $B$ and has $A$ genes) are summarized in Table 4. 
Table 4. Engineered microorganisms for HA production, strain construction strategy, HA titers, and molecular weight. Only recombinant strains containing has $A$ and has $B$ genes were considered here.

\begin{tabular}{|c|c|c|c|c|c|c|c|c|}
\hline Microorganism & HasA Source & Promoter & Strain Name & HA (g/L) & $\begin{array}{c}\text { Molecular } \\
\text { Weight (MDa) }\end{array}$ & $\begin{array}{l}\text { Quantification } \\
\text { Method }\end{array}$ & $\begin{array}{c}\text { Substrate } \\
\text { Initial } \\
\text { Concentration }\end{array}$ & Ref. \\
\hline $\begin{array}{c}\text { Enterococcus faecalis } \\
\text { Escherichia coli }\end{array}$ & S. pyogenes & $-^{\mathrm{a}}$ & $--^{\mathrm{a}}$ & $\begin{array}{l}0.69 \\
0.08\end{array}$ & $-^{a}$ & Carbazole & $--^{\mathrm{a}}$ & [44] \\
\hline Bacillus subtilis & S. equisimilis & $\mathrm{P}_{a m y Q^{-C o n s t i t u t i v e ~}}$ & RB184 & 0.81 & 1.2 & Carbazole & $-b$ & [45] \\
\hline Lactococcus lactis & S. zooepidemicus & $\mathrm{P}_{N i s A}$-Inductive & LL-NAB & 0.65 & $-{ }^{a}$ & HPLC & $10 \mathrm{~g} / \mathrm{L}$ & [46] \\
\hline Bacillus subtilis & S. zooepidemicus & $\mathrm{P}_{\text {VegII }}$-Constitutive & RB-AB & 0.84 & $-{ }^{a}$ & Carbazole & $10 \mathrm{~g} / \mathrm{L}$ & [47] \\
\hline Agrobacterium sp. & P. multocida & Phage T5-Inductive & АТCС 31749 & 0.3 & $0.7-2$ & Carbazole & $42 \mathrm{~g} / \mathrm{L}$ & [22] \\
\hline Escherichia coli & $\begin{array}{l}\text { S. equisimilis } \\
\text { S. pyogenes }\end{array}$ & $\mathrm{P}_{B A D}$-Inductive & $\begin{array}{l}\text { sseAB } \\
\operatorname{spAB}\end{array}$ & $\begin{array}{c}0.2 \\
0.01\end{array}$ & 1.9 & Carbazole & $16 \mathrm{~g} / \mathrm{L}$ & [46] \\
\hline Escherichia coli & P. multocida & Phage T5-Inductive & JM109/pHK & 0.55 & 1.5 & Carbazole & $45 \mathrm{~g} / \mathrm{L}$ & [18] \\
\hline Lactococcus lactis & S. zooepidemicus & $\mathrm{P}_{\text {NisA }}$-Inductive & NFHA01 & 0.59 & 0.88 & Radioimmunoassay & $20 \mathrm{~g} / \mathrm{L}$ & [48] \\
\hline Lactococcus lactis & S. zooepidemicus & $\mathrm{P}_{N i s A}$-Inductive & SJR2 & 0.11 & 2.8 & Carbazole & $15 \mathrm{~g} / \mathrm{L}$ & [49] \\
\hline Bacillus subtilis & P. multocida & Inductive & $-^{c}$ & $-^{c}$ & 5.43 & Carbazole & $20 \mathrm{~g} / \mathrm{L}$ & [20] \\
\hline Lactococcus lactis & S. zooepidemicus & $\mathrm{P}_{N i s A}$-Inductive & VRJ2AB & 0.14 & 4.30 & Carbazole & $10 \mathrm{~g} / \mathrm{L}$ & [50] \\
\hline Pichia pastoris & Xenopus laevis & $\begin{array}{c}\mathrm{P}_{G A P} \text {-Constitutive } \\
\mathrm{P}_{A O X 1} \text {-Inductive }\end{array}$ & EJ & 0.2 & 0.25 & Carbazole & $40 \mathrm{~g} / \mathrm{L}$ & [26] \\
\hline Streptomyces albulus & S. zooepidemicus & $\mathrm{P}_{P L S}$-Inductive & pJHA3 & 5.1 & 2 & Carbazole & ${ }^{d} 60 \mathrm{~g} / \mathrm{L}$ & [24] \\
\hline Bacillus subtilis & S. zooepidemicus & $\mathrm{P}_{x y l A}$-Inductive & pP43-D & 2.05 & 1.76 & Carbazole & $50 \mathrm{~g} / \mathrm{L}$ & [19] \\
\hline Corynebacterium glutamicum & S. equisimilis & $\begin{array}{l}\mathrm{P}_{\mathrm{SOD}} \text {-Constitutive } \\
\mathrm{P}_{\mathrm{dapB}} \text {-Constitutive }\end{array}$ & pXMJ19-PdapB & $\begin{array}{l}-\mathrm{a} \\
0.14\end{array}$ & $\begin{array}{l}-{ }^{a} \\
-{ }^{a}\end{array}$ & СТAB & $40 \mathrm{~g} / \mathrm{L}$ & [23] \\
\hline Corynebacterium glutamicum & S. equisimilis & $\mathrm{P}_{\text {TAC }}$-Inductive & $\mathrm{AB}$ & 5.4 & 1.28 & СТАВ & $40 \mathrm{~g} / \mathrm{L}$ & [51] \\
\hline Bacillus subtilis & S. equisimilis & $\mathrm{P}_{G R A C}$-Inductive & AW008 & 0.48 & 1.95 & Carbazole & $20 \mathrm{~g} / \mathrm{L}$ & [21] \\
\hline Kluyveromyces lactis & P. multocida & $\mathrm{P}_{L A C 4}$-Inductive & BAP & 1.89 & 2.09 & Carbazole & $40 \mathrm{~g} / \mathrm{L}$ & This study \\
\hline
\end{tabular}

${ }^{a}$. Information not available. ${ }^{b}$. The initial concentration of substrate during fermentation is not cited. ${ }^{c}$. No results were presented by study with strains containing only the has $A$ and has $B$ genes. ${ }^{d}$. The glucose concentration was maintained at $5 \%$ by a feed pump. 
Most strains presented in Table 4 use the has A gene from Streptococcus equi subsp. zooepidemicus while here, the class II has $A$ gene, from Pasteurella multocida was successfully inserted for the first time in $K$. lactis and resulted in maximum HA production of $1.89 \mathrm{~g} / \mathrm{L}$. HA production by BAP strain was also confirmed by electron microscopic analysis similarly to previous studies [52].

Among studies with yeasts, only P. pastoris is listed in Table 4. Differently, from P. pastoris, the Lac4 promoter of $K$. lactis is not repressed by glucose or other carbon sources. The insertion of has $A$ and has $B$ genes in P. pastoris resulted in an HA production of $200 \mathrm{mg} / \mathrm{L}$, value approximately 9.5 times lower than the obtained here using K. lactis with the same genetic modifications. Furthermore, the highest HA concentration in P. pastoris is $\sim 10 \%$ lower than the titers reached by K. lactis.

On the contrary, no HA could be detected in the recombinant $K$. lactis strains where three different Homo sapiens has $A$ genes were introduced even though the transcripts of has $A$ genes could be detected in BA1 and BA3. The human has A genes have been previously characterized [12] whereas it has been suggested that once translated, these enzymes should pass to an unknown regulatory process before coupling it to the cell membrane. Furthermore, the mammalian HAS enzymes have eight domains which six are transmembrane ones, and two are membrane associated [52] which makes its insertion into the yeast membrane challenging. Another reason for the lack of activity on the recombinant strains containing the human has $A$ genes could be post-translation regulation. It has been previously shown that has $A 2$, for example, can be strongly inhibited by AMPK by phosphorylation of a threonine residue in this enzyme [53]. Furthermore, other molecules such as EGF, FGF2, FGF, Forskolin, IGF, IL- $1 \beta$, PDGF, Progesterone, Prostaglandin, TGF- $\beta$, Estradiol, $4-M U$, TGF- $\beta 1$, and TGF- $\beta 1$ have been previously described to control human HAS activities [54]. Since none of them are present in $K$. lactis this could justify the absence of activity of these enzymes. In addition, various studies suggest that human HAS enzymes can undergo a wide variety of post-translational modifications that can regulate the enzyme activity [52]. One of them is the glycosylation pattern, where O-GlcNAcylation and mono-ubiquitination were reported to influence HAS activities. Since the trend of mammalian glycosylation modifications is different from one found in yeasts, this may also have caused the absence of human HAS activities K. lactis. Altogether it can be said that although transcripts of hshas $A 1$ and hshas $A 3$ genes were detected in strains BA1 and BA3 respectively, a translation failure or more likely incorrect coupling of HAS enzymes into the yeast membrane may have prevented the enzyme activity.

Among the 17 strains listed in Table 4, only three $[19,24,53]$ showed HA titers higher than those obtained in this study. However, in one of them [24], the HA production of $5.1 \mathrm{~g} / \mathrm{L}$ with Streptomyces albulus has been achieved maintaining the glucose concentration at $5 \%$ in a fed-batch mode. The other study with Corynebacterium glutamicum [53] achieved an HA production (5.1 g/L) 2.85 times higher than K. lactis with the same initial substrate concentration. However, in Corynebacterium glutamicum, a strategy of gene induction with the PTAC promoter (IPTG induction after initial growth) was utilized, while in K. lactis HA was produced during the entire growth phase. Finally, in Bacillus subtilis [19], HA production was $\sim 8 \%$ higher, however, a higher concentration of substrate was used in relation to K. lactis.

As shown in Table 4, the Carbazole method [41] for HA quantification was used in 13 of the 17 studies. The carbazole protocol is based in the quantification of GlcUA present in a sample. For this, the HA must be previously hydrolyzed from the HA chains with a strong acid $\left(\mathrm{H}_{2} \mathrm{SO}_{4}\right)$ treatment at high temperature $\left(100^{\circ} \mathrm{C}\right)$. The carbazole method is accurate but is strongly influenced by residual concentrations of salts and carbon sources present in the medium [55] that are co-purified together with HA. The impurities present in the sample react with $\mathrm{H}_{2} \mathrm{SO}_{4}$ during hydrolysis changing the Carbazole assay color and giving overestimated results. In this study, the HA purified from growth in shake flasks could not be properly determined due to impurities of the rich medium (YPD) (data not shown). Therefore, HA titer is only reported from culture supernatant using defined medium. Finally, the protocol for Carbazole method utilized for HA quantification in K. lactis is identical to protocol utilized in most of the 13 studies shown in Table 4, and the Calibration Curve is presented in Figure S23. 
Regarding HA Molecular Weight, only a minority of strains (Table 4) achieved similar values. Usually, HA applications depend on its molecular weight for example in mammals, high molecular HA weight ( $>1 \mathrm{MDa}$ ) have a role in maintaining cell integrity [56], while low molecular weight chains $\left(<10^{4} \mathrm{Da}\right)$ are used as receptors and signaling agents during cell communication [54]. In this study, the HA produced by K. lactis in defined medium reached 2.09 MDa by using GPC analysis. Although GPC analysis may result in an overestimation of up to two times [57], any values above $1 \mathrm{MDa}$ are considered high molecular weight HA [2]. In addition, it is important to emphasize that the GPC analysis of the standard HA utilized in this study showed a value of 1.3 MDa while the supplier information determined it as $1.5 \mathrm{MDa}$ (Figure S22) which shows that the error of the GPC assay is not higher than $16 \%$.

The concentration of HA above $2 \mathrm{~g} / \mathrm{L}$ simultaneously with a high molecular weight (>1 MDa) is rare since it has been reported that there is an inverse relation regarding HA titers and molecular weight [52]. Besides, the ratio among Glucuronic Acid and N-Acetyl Glucosamine have also shown to influence HA molecular weight and concentration. For example, in S. zooepidemicus, the overexpression of genes from the UDP-Glucuronic Acid synthesis pathway decreases the molecular weight of the HA and increases its titers, whereas the overexpression of the UDP-N-Acetyl Glucosamine has the opposite effect [58]. On the contrary, in Bacillus subtillis, when the three genes, has $A$, hasB, and has C involved in the synthesis of UDP-Glucuronic Acid were super expressed, the resulting HA had an increased molecular weight when compared to the recombinant strain where the levels of Glucuronic Acid and $\mathrm{N}$-Acetyl Glucosamine were balanced by the overexpression of hasD [20]. Therefore, the influence of precursor concentration and activities of critical enzymes is suggested to be cell-dependent and yet needs to be further investigated in K. lactis.

The metabolic pathway for HA synthesis highlights how energetically costly the polymer synthesis is for the host cell (Figure 1). The production of one monomer of HA requires 3 ATP, 2 UTP, 2 NAD $^{+}$, 1 Acetyl-CoA, and one glutamine. Indeed, availability of ATP has been shown to increase HA production. For example, the utilization of Streptomyces albulus, a bacterium able to synthesize ATP molecules at a higher level when compared to other bacteria, as host of HA production was able to produce up to $6.2 \mathrm{~g} / \mathrm{L}$ of HA [24], one of the highest HA titers reported up to now. Furthermore, HA synthesis generates an accumulation of NADH. Therefore, to keep the cell redox balance during HA synthesis, it is necessary to activate metabolic pathways that reoxidize NADH. K. lactis is a Crabtree-negative yeast and does not produce ethanol under aerobic conditions. This was corroborated here in aerobic batch fermentation (Table 3). Nevertheless, the introduction of xlhasB and pmhas $A$ genes resulted in an increase of approximately seven times in ethanol yield in the BAP strain (Table 3) probably to favor recycling of $\mathrm{NAD}^{+}$. In contrast, decreased glycerol production in the modified BAP strain was not expected since glycerol production also reoxidizes NADH. Nevertheless, the fructose 6-phosphate precursor is both used in HA and glycerol synthesis (Figure 1). Thus, this shift may have caused the reduction of glycerol formation in the cell. Finally, in both shake flasks and bioreactor fermentations, HA synthesis did not affect the yeast growth rate $\left(\mu_{\mathrm{MAX}}\right)$ but decreased the biomass yield from glucose in comparison with the wild type.

\section{Conclusions}

The addition of human has $A$ genes in K. lactis genome does not result in the synthesis of Hyaluronic Acid. However, the addition of the has $A$ gene from Pasteurella multocida in combination with the has $B$ gene from Xenopus leavis enabled HA production at the concentration of $1.89 \mathrm{~g} / \mathrm{L}$ with a molecular weight of 2.09 MDa. This HA production does not affect the yeast growth rate compared to the wild-type strain, but changes the final yield of biomass, glycerol, and ethanol. Altogether our results are the proof of principle for HA production in K. lactis having competitive titers when compared to other microorganisms. It can be used as a basis for the development of an industrial bioprocess for HA production using K. lactis as the biocatalyst. 
Supplementary Materials: The following are available online at http://www.mdpi.com/2076-2607/7/9/294/s1, Figures S1 to S11: Plasmid Maps, Sequences S1 to S11: Gene Sequences; Table S1: Primers utilized in the study, Figures S12 and S13: RNA integrity gels, Figures S14 to S18: Melt Curve Analysis, Figure S19: Kinetic Growth of strains, Figure S20: Transcripts level analysis, Figure S21: Copy Gene Number Analysis, Figure S22: GPC Analysis of Standard HA, Figure S23: Carbazol standard curve.

Author Contributions: A.M.V.G., J.H.C.M.N., and L.S.C. performed the experiments. A.M.V.G and J.H.C.M.N. analyzed the data. A.M.V.G. drafted the manuscript. N.S.P. commented on the manuscript. N.S.P. conceived and coordinated the study and revised the manuscript. All authors read and approved the final manuscript.

Funding: This project has received funding from Brazilian National Council for Scientific and Technological Development (CNPq) and Fundação de Apoio a Pesquisa do Distrito Federal (FAP-DF).

Acknowledgments: Dra. Sônia Nair Bao and Laboratório de Microscopia e Microanálises (LMM) of the University of Brasília for having performed and assisted in the use and processes involved in electron microscopy analyzes used in this study.

Conflicts of Interest: The authors declare no conflict of interest.

\section{References}

1. Liu, L.; Liu, Y.; Li, J.; Du, G.; Chen, J. Microbial production of hyaluronic acid: Current state, challenges, and perspectives. Microb. Cell Fact. 2011, 10, 99. [CrossRef]

2. de Oliveira, J.D.; Carvalho, L.S.; Gomes, A.M.V.; Queiroz, L.R.; Magalhães, B.S.; Parachin, N.S. Genetic basis for hyper production of hyaluronic acid in natural and engineered microorganisms. Microb. Cell Fact. 2016, 15, 119. [CrossRef]

3. Long, M.; Fu, M.; Liu, Y.; Cao, H.; Lin, Y.L. Capsular hyaluronic acid of Cryptococcus neoformans contributes to fungal invasion across the alveolar-capillary interface. Int. J. Infect. Dis. 2014, 21, 282. [CrossRef]

4. Gandhi, N.S.; Mancera, R.L. The structure of glycosaminoglycans and their interactions with proteins. Chem. Biol. Drug Des. 2008, 72, 455-482. [CrossRef]

5. Research, G.V. Hyaluronic Acid Market Size Worth \$15.25 Billion By 2026 | CAGR 7.8\%. Available online: https://www.grandviewresearch.com/press-release/global-hyaluronic-acid-market (accessed on 29 July 2019).

6. Greenberg, D.D.; Stoker, A.; Kane, S.; Cockrell, M.; Cook, J.L. Biochemical effects of two different hyaluronic acid products in a co-culture model of osteoarthritis. Osteoarthr. Cartil. 2006, 14, 814-822. [CrossRef]

7. Kogan, G.; Šoltés, L.; Stern, R.; Gemeiner, P. Hyaluronic acid: A natural biopolymer with a broad range of biomedical and industrial applications. Biotechnol Lett. 2007, 29, 17-25. [CrossRef]

8. Spicer, A.P.; Seldin, M.F.; Olsen, A.S.; Brown, N.; Wells, D.E.; Doggett, N.A.; Itano, N.; Kimata, K.; Inazawa, J.; McDonald, J.A. Chromosomal localization of the human and mouse hyaluronan synthase genes. Genomics 1997, 41, 493-497. [CrossRef]

9. DeAngelis, P.L. Hyaluronan synthases: Fascinating glycosyltransferases from vertebrates, bacterial pathogens, and algal viruses. Cell. Mol. Life Sci. 1999, 56, 670-682. [CrossRef]

10. DeAngelis, P.L. Enzymological characterization of the Pasteurella multocida hyaluronic acid synthase. Biochemistry 1996, 35, 9768-9771. [CrossRef]

11. DeAngelis, P.L. Molecular directionality of polysaccharide polymerization by the Pasteurella multocida hyaluronan synthase. J. Biol. Chem. 1999, 274, 26557-26562. [CrossRef]

12. Itano, N.; Sawai, T.; Yoshida, M.; Lenas, P.; Yamada, Y.; Imagawa, M.; Shinomura, T.; Hamaguchi, M.; Yoshida, Y.; Ohnuki, Y.; et al. Three isoforms of mammalian hyaluronan synthases have distinct enzymatic properties. J. Biol. Chem. 1999, 274, 25085-25092. [CrossRef]

13. Weigel, P.H.; DeAngelis, P.L. Hyaluronan synthases: A decade-plus of novel glycosyltransferases. J. Biol. Chem. 2007, 282, 36777-36781. [CrossRef]

14. Necas, J.; Bartosikova, L.; Brauner, P.; Kolar, J. Hyaluronic acid (hyaluronan): A review. Vet. Med. (Praha). 2008, 53, 397-411. [CrossRef]

15. Kendall, F.E.; Heidelberger, M.; Dawson, M.H. A serologically inactive polysaccharide elaborated by mucoid strains of Group A Streptococcus. J. Biol. Chem. 1937, 61-69.

16. Kim, J.H.; Yoo, S.J.; Oh, D.K.; Kweon, Y.G.; Park, D.W.; Lee, C.H.; Gil, G.H. Selection of a Streptococcus equi mutant and optimization of culture conditions for the production of high molecular weight hyaluronic acid. Enzym. Microb. Technol. 1996, 19, 440-445. [CrossRef] 
17. Chien, L.J.; Lee, C.K. Hyaluronic acid production by recombinant Lactococcus lactis. Appl. Microbiol. Biotechnol. 2007, 77, 339-346. [CrossRef]

18. Mao, Z.; Shin, H.D.; Chen, R. A recombinant E. coli bioprocess for hyaluronan synthesis. Appl. Microbiol. Biotechnol. 2009, 84, 63-69. [CrossRef]

19. Jin, P.; Kang, Z.; Yuan, P.; Du, G.; Chen, J. Production of specific-molecular-weight hyaluronan by metabolically engineered Bacillus subtilis 168. Metab. Eng. 2016, 35, 21-30. [CrossRef]

20. Jia, Y.; Zhu, J.; Chen, X.; Tang, D.; Su, D.; Yao, W.; Gao, X. Metabolic engineering of Bacillus subtilis for the efficient biosynthesis of uniform hyaluronic acid with controlled molecular weights. Bioresour. Technol. 2013, 132, 427-431. [CrossRef]

21. Westbrook, A.; Ren, X.; Oh, J.; Moo-Young, M.; Chou, C. Metabolic engineering to enhance heterologous production of hyaluronic acid in Bacillus subtilis. Metab. Eng. 2018. [CrossRef]

22. Mao, Z.; Chen, R.R. Recombinant synthesis of hyaluronan by Agrobacterium sp. Biotechnol. Prog. 2007, 23, 1038-1042. [CrossRef]

23. Cheng, F.; Gong, Q.; Yu, H.; Stephanopoulos, G. High-titer biosynthesis of hyaluronic acid by recombinant Corynebacterium glutamicum. Biotechnol. J. 2016, 11, 574-584. [CrossRef]

24. Yoshimura, T.; Shibata, N.; Hamano, Y.; Yamanaka, K. Heterologous production of hyaluronic acid in an $\varepsilon$-Poly-L-Lysine producer, Streptomyces albulus. Appl. Environ. Microbiol. 2015, 81, 3631-3640. [CrossRef]

25. Jung, Y.; Jung, M.Y.; Park, J.H.; Jung, G.C.; Hong, Y.S.; Yeom, C.H.; Lee, S. Production of human hyaluronidase in a plant-derived protein expression system: Plant-based transient production of active human hyaluronidase. Protein Expr. Purif. 2010, 74, 181-188. [CrossRef]

26. Jeong, E.; Shim, W.Y.; Kim, J.H. Metabolic engineering of Pichia pastoris for production of hyaluronic acid with high molecular weight. J. Biotechnol. 2014, 185, 28-36. [CrossRef]

27. Rodicio, R.; Heinisch, J.J. Yeast on the milky way: Genetics, physiology and biotechnology of Kluyveromyces lactis. Yeast 2013, 30, 165-177. [CrossRef]

28. Dujon, B.; Sherman, D.; Fischer, G.; Durrens, P.; Casaregola, S.; Lafontaine, I.; De Montigny, J.; Marck, C.; Neuvéglise, C.; Talla, E.; et al. Genome evolution in yeasts. Nature 2004, 430, 35-44. [CrossRef]

29. van Ooyen, A.; Dekker, P.; Huang, M.; Olsthoorn, M.; Jacobs, D.I.; Colussi, P.A.; Taron, C.H. Heterologous protein production in the yeast Kluyveromyces lactis. Fed. Eur. Microbiol. Soc. 2006, 381-392.

30. Itano, N.; Kimata, K. Mammalian Hyaluronan Synthases. IUBMB Life 2002, 1, 195-199. [CrossRef]

31. Siiskonen, H.; Oikari, S.; Pasonen-Seppänen, S.; Rilla, K. Hyaluronan synthase 1: A mysterious enzyme with unexpected functions. Front. Immunol. 2015, 6, 1-11. [CrossRef]

32. Sussmann, M.; Sarbia, M.; Meyer-Kirchrath, J.; Nüsing, R.M.; Schrör, K.; Fischer, J.W. Induction of Hyaluronic Acid Synthase 2 (HAS2) in Human Vascular Smooth Muscle Cells by Vasodilatory Prostaglandins. Circ. Res. 2004, 94, 592-600. [CrossRef]

33. Makkonen, K.M.; Pasonen-Seppänen, S.; Törrönen, K.; Tammi, M.I.; Carlberg, C. Regulation of the hyaluronan synthase 2 gene by convergence in cyclic AMP response element-binding protein and retinoid acid receptor signaling. J. Biol. Chem. 2009, 284, 18270-18281. [CrossRef]

34. Cifonelli, J.A.; Rebers, P.A.; Heddleston, K.H. The isolation and characterization of hyaluronic acid from Pasteurella multocida. Carbohydr. Res. 1970, 14, 272-276. [CrossRef]

35. Müllegger, J.; Lepperdinger, G. Hyaluronan is an abundant constituent of the extracellular matrix of Xenopus embryos. Mol. Reprod. Dev. 2002, 61, 312-316. [CrossRef]

36. Hanahan, D.; Jessee, J.; Bloom, F.R. Bacterial Genetic Systems. Methods Enzymol. 1991, 204, 63-113.

37. Im, J.H.; Song, J.M.; Kang, J.H.; Kang, D.J. Optimization of medium components for high-molecular-weight hyaluronic acid production by Streptococcus sp. ID9102 via a statistical approach. J. Ind. Microbiol. Biotechnol. 2009, 36, 1337-1344. [CrossRef]

38. Aranda, P.S.; Lajoie, D.M.; Jorcyk, C.L. Bleach gel: A simple agarose gel for analyzing RNA quality. Electrophoresis 2012, 33, 366-369. [CrossRef]

39. Ma, L.; Chung, W.K. Quantitative analysis of copy number variants based on real-time lightcycler PCR. Curr. Protoc. Hum. Genet. 2014.

40. Das Murtey, M.; Ramasamy, P. Sample Preparations for Scanning Electron Microscopy-Life Sciences. Mod. Electron Microsc. Phys. Life Sci. 2016.

41. Bitter, T.; Muir, H.M. A modified uronic acid carbazole reaction. Anal. Biochem. 1962, 4, 330-334. [CrossRef] 
42. Jong, A.; Wu, C.H.; Chen, H.M.; Luo, F.; Kwon-Chung, K.J.; Chang, Y.C.; LaMunyon, C.W.; Plaas, A.; Huang, S.H. Identification and characterization of CPS1 as a hyaluronic acid synthase contributing to the pathogenesis of Cryptococcus neoformans infection. Eukaryot Cell 2007, 6, 1486-1496. [CrossRef]

43. Deangelist, P.L.; Achyuthan, A.M. Yeast-derived recombinant DG42 protein of Xenopus can synthesize hyaluronan in vitro. J. Biol. Chem. 1996, 271, 23657-23660. [CrossRef]

44. DeAngelis, P.L.; Papaconstantinou, J.; Weigel, P.H. Isolation of a Streptococcus pyogenes gene locus that directs hyaluronan biosynthesis in acapsular mutants and in heterologous bacteria. J. Biol. Chem. 1993, 268, 14568-14571.

45. Widner, B.; Von Dollen, S.; Tang, M.; Heu, T.; Sloma, A.; Sternberg, D.; Deangelis, P.L.; Weigel, P.H.; Brown, S. Hyaluronic Acid Production in Bacillus subtilis. Appl. Environ. Microbiol. 2005, 71, 3747-3752. [CrossRef]

46. Yu, H.; Stephanopoulos, G. Metabolic engineering of Escherichia coli for biosynthesis of hyaluronic acid. Metab. Eng. 2008, 10, 24-32. [CrossRef]

47. Chien, L.J.; Lee, C.K. Enhanced hyaluronic acid production in Bacillus subtilis by coexpressing bacterial hemoglobin. Biotechnol. Prog. 2007, 23, 1017-1022. [CrossRef]

48. Sheng, J.Z.; Ling, P.X.; Zhu, X.Q.; Guo, X.P.; Zhang, T.M.; He, Y.L.; Wang, F.S. Use of induction promoters to regulate hyaluronan synthase and UDP-glucose-6-dehydrogenase of Streptococcus zooepidemicus expression in Lactococcus lactis: A case study of the regulation mechanism of hyaluronic acid polymer. J. Appl. Microbiol. 2009, 107, 136-144. [CrossRef]

49. Prasad, S.B.; Jayaraman, G.; Ramachandran, K.B. Hyaluronic acid production is enhanced by the additional co-expression of UDP-glucose pyrophosphorylase in Lactococcus lactis. Appl. Microbiol. Biotechnol. 2010, 86, 273-283. [CrossRef]

50. Hmar, R.V.; Prasad, S.B.; Jayaraman, G.; Ramachandran, K.B. Chromosomal integration of hyaluronic acid synthesis (has) genes enhances the molecular weight of hyaluronan produced in Lactococcus lactis. Biotechnol. J. 2014, 9, 1554-1564. [CrossRef]

51. Cheng, F.; Luozhong, S.; Guo, Z.; Yu, H.; Stephanopoulos, G. Enhanced Biosynthesis of Hyaluronic Acid Using Engineered Corynebacterium glutamicum Via Metabolic Pathway Regulation. Biotechnol. J. 2017. [CrossRef]

52. Vigetti, D.; Viola, M.; Karousou, E.; De Luca, G.; Passi, A. Metabolic control of hyaluronan synthases. Matrix Biol. 2014, 35, 8-13. [CrossRef]

53. Vigetti, D.; Clerici, M.; Deleonibus, S.; Karousou, E.; Viola, M.; Moretto, P.; Heldin, P.; Hascall, V.C.; De Luca, G.; Passi, A. Hyaluronan synthesis is inhibited by adenosine monophosphate-activated protein kinase through the regulation of HAS2 activity in human aortic smooth muscle cells. J. Biol. Chem. 2011, 286, 7917-7924. [CrossRef]

54. Stern, R.; Asari, A.A.; Sugahara, K.N. Hyaluronan fragments: An information-rich system. Eur. J. Cell Biol. 2006, 85, 699-715. [CrossRef]

55. Song, J.M.; Im, J.H.; Kang, J.H.; Kang, D.J. A simple method for hyaluronic acid quantification in culture broth. Carbohydr. Polym. 2009, 78, 633-634. [CrossRef]

56. Price, R.D.; Berry, M.G.; Navsaria, H.A. Hyaluronic acid: The scientific and clinical evidence. J. Plast. Reconstr. Aesthetic Surg. 2007, 60, 1110-1119. [CrossRef]

57. Shanmuga Doss, S.; Bhatt, N.P.; Jayaraman, G. Improving the accuracy of hyaluronic acid molecular weight estimation by conventional size exclusion chromatography. J. Chromatogr. B Anal. Technol. Biomed. Life Sci. 2017, 1060, 255-261. [CrossRef]

58. Chen, S.J.; Chen, J.L.; Huang, W.C.; Chen, H.L. Fermentation process development for hyaluronic acid production by Streptococcus zooepidemicus ATCC 39920. Korean J. Chem. Eng. 2009, 26, 428-432. [CrossRef]

(C) 2019 by the authors. Licensee MDPI, Basel, Switzerland. This article is an open access article distributed under the terms and conditions of the Creative Commons Attribution (CC BY) license (http://creativecommons.org/licenses/by/4.0/). 